\title{
Aligning community-based water monitoring program designs with goals for enhanced environmental management
}

\section{Amy Buckland-Nicks, Heather Castleden and Cathy Conrad}

\begin{abstract}
Community-based water monitoring (CBWM) provides essential baseline information on watershed health and engages the public in science, but those involved often encounter barriers to informing environmental management. We conducted qualitative interviews with watershed group coordinators and government counterparts from four CBWM organizations to explore instances where CBWM successfully influenced governmental decision-making. Our findings show that the level of rigor for quality standards, inclusion of volunteers, available resources, and desired goals are important considerations when designing community-based monitoring programs. Integrated program designs that include adequate quality standards and engage volunteers are more apt to maximize resources and realize both scientific and educational goals.
\end{abstract}

Keywords

Citizen science; Participation and science governance; Public engagement with science and technology

Water resource management, and environmental management more broadly, has been affected by government decentralization in Canada [Bakker and Cook, 2011] and reduced government capacity for monitoring [Pilon et al., 1996; WCEL, 2004; Water Canada, 2010]. 'Citizen scientists,' or lay people who become actively engaged in scientific research projects, have begun to fill this information gap by collecting environmental monitoring data on ecosystem health [Wieler, 2007; Au et al., 2000; Conrad and Hilchey, 2011; Savan, Morgan and Gore, 2003].

Community-based monitoring (CBM) is a 'process where concerned citizens, government agencies, industry, academia, community groups and local institutions collaborate to monitor, track and respond to issues of common community concern' [Whitelaw et al., 2003, p. 410]. CBM is part of the broader citizen science movement, which has involved millions of volunteers and non-government organization (NGO) employees at regional, national, and global scales in scientific inquiry, including tracking and recording of ecological change [Bonney et al., 2014; Dickinson et al., 2012]. The term 'community-based monitoring' is often used interchangeably with 'volunteer monitoring', which includes community-based research projects, government-led, and other institution-led initiatives [Overdevest, Huyck Orr and Stepenuck, 2004]. The study reported on here is concerned with 
community-based water monitoring (CBWM), where community groups partner with other organizations to measure water quality parameters of their local watersheds, including, for example, dissolved oxygen, $\mathrm{pH}$, coliforms, and total dissolved solids. We focus on CBWM programs that engage both volunteers and NGO staff and range from being institution or government-led to community-led initiatives.

The engagement of community volunteers and NGO staff in CBWM has provided many benefits for science communication with water resource management. Documented benefits include increased access to information at a reduced cost [Cuthill, 2000; Conrad and Daoust, 2008], enhanced public participation in environmental management [Whitelaw et al., 2003; Au et al., 2000], democratization of science [Conrad and Hilchey, 2011; Ely, 2008], and increased social capital [Bliss et al., 2001]. Citizens engaged in CBWM often expect that their data will help to inform governmental decision-making concerning environmental management [Conrad and Daoust, 2008]. However, many challenges make it difficult to connect CBWM information with environmental management [Conrad and Hilchey, 2011], including, for example, inconsistent funding and data collection [Bliss et al., 2001], volunteer burnout [Conrad, 2006], and concerns with data accuracy [Legg and Nagy, 2006]. But, studies have shown that community volunteers can collect quality data that is comparable to professionals' data [Danielsen et al., 2014; Shelton, 2013], especially when properly trained [Fore, Paulsen and O'Laughlin, 2001; Shelton, 2013]. When adequate resources are invested, CBWM has the potential to enhance public participation and access to information, which have been highlighted as important for water resource management [Jønch-Clausen and Fugl, 2001].

There is a diversity of types of CBWM programs, which reflects a variety of motivations for conducting CBWM. Reasons that citizens engage in CBWM have included, for example, responding to a perceived environmental threat, producing baseline information in its absence, and promoting community awareness about local conditions [Bliss et al., 2001]. Government agencies have initiated CBWM programs in order to cover broader geographic areas for long-term baseline monitoring and to raise awareness of watershed health [Community Aquatic Monitoring Program (CAMP); Milne et al., 2006]. Meanwhile, academic institutions that initiate such programs often have strong scientific missions (e.g., the long-established Cornell Lab of Ornithology). In any case, the scholarly community has identified four main types of CBWM [modified from Whitelaw et al., 2003], which arise from these different reasons for monitoring:

1. Government-led monitoring, which is often directed by government and includes community members in data collection.

2. Multiparty monitoring, which involves collaboration between government agencies, NGOs, academic and other formal institutions, and/or other stakeholders in monitoring an issue of common concern.

3. Advocacy monitoring, which is directed and undertaken by communities for addressing a particular issue, often with the intent of inspiring action.

4. Interpretive or educational monitoring, which is focused on educating the community through public participation, including volunteer involvement. 
Some monitoring programs may constitute a combination of these types, for example university-led monitoring that engages a wide base of volunteers in rigorous scientific sampling could be seen as a branch of multiparty monitoring (see Savan, Morgan, and Gore, 2003). At any rate, there has been a focus in recent literature on CBWM that can be linked with governmental decision-making, with general agreement that multiparty monitoring is the most effective [Whitelaw et al., 2003; Milne et al., 2006; Conrad and Daoust, 2008]. Meanwhile, advocacy monitoring has been linked to localized success with influencing decision-making involving 'hotspot' water quality issues that involve a point source [Hunsberger, 2004] and educational aspects of monitoring have been promoted for enhancing community awareness [Cuthill, 2000; Firehock and West, 1995]. Recommendations for success with citizen science have often been focused on scientific contributions alone, but success can be defined differently depending on the reasons for monitoring [Freitag and Pfeffer, 2013]. Consequently, each type of CBWM can make meaningful contributions to management and achieve success when considering their slightly different goals.

The identification of monitoring goals, particularly through a collaborative process, has been suggested to be a key step in designing CBWM and other monitoring programs that can contribute to enhancing environmental management [Conrad and Daoust, 2008; Wieler, 2007]. Meanwhile, several studies have shown instances where organizations engaged in CBWM have not properly identified goals or have mismatched monitoring designs and goals [Nerbonne and Nelson, 2008; Conrad and Daoust, 2008; Kebo and Bunch, 2013]. For example, Conrad and Daoust [2008] found that 82 percent of Nova Scotia (Atlantic Canada) watershed group survey respondents had attempted to deliver their monitoring information to government decision-makers, but none could confirm whether their data had been used. Meanwhile, 72 percent of respondents said they did not use consistent monitoring methods or standards. In light of this finding, a functional framework was created to help guide community-based organizations in producing a comprehensive monitoring plan [Conrad and Daoust, 2008]. Resources have been developed for guiding volunteer monitoring program designs elsewhere; for example, in the United States as part of the Volunteer Water Quality Monitoring National Facilitation Project [Herron et al., 2003]. However, as of yet, there has been limited guidance in the peer-reviewed literature on the effectiveness of different monitoring designs for attaining desired goals and thus connecting the information with end-users. Connections between governmental and academic water research and water management have also been lacking [Dorcey, 1987; Pearse, Bertrand and MacLaren, 1986], pointing to the greater challenge of linking scientific information with environmental management [Sutherland et al., 2004; Vaughan et al., 2003]. These ongoing challenges for CBWM and governmental (and other institutional forms of) monitoring indicate a need to understand the diverse roles of monitoring information in adaptive and integrated management of our watersheds.

When CBWM does not attain its goal - whether it is to do with engaging communities, validating restoration projects, or influencing decision-making - it can turn into 'monitoring for the sake of monitoring,' which can waste valuable resources and contribute to volunteer burnout [Conrad, 2006]. Our research objective was to explore how and why CBWM was 'successfully' linked with governmental decision-making. Over the course of our study involving four 
CBWM organization case studies, we identified an emergent theme about linking CBWM designs with goals and roles in environmental management, which warranted further or secondary analysis. Thus, in this article, we share findings from our qualitative analysis of semi-structured interviews with watershed group coordinators and government decision-makers from four case study groups across Canada that help to distinguish between the three main CBWM design categories of intensive, integrated, and basic monitoring and their suitability for different roles in environmental management. This research aims to help watershed groups and their partners design CBWM programs that can realize diverse goals for enhancing environmental management.

The research reported here arises from a study that investigated the factors contributing to successful integration of CBWM in governmental decision-making. Similarly to Castleden and colleagues' [2010] study involving an unintended line of inquiry, we identified an emergent theme through inductive coding that warranted further analysis. As noted in the introduction, this paper explores the emergent theme of linkages between monitoring designs and goals. We outline the overall study design below.

Four case study watershed groups were selected from across Canada using a database of environmental stewardship groups engaged in community-based environmental monitoring that was produced by Lefler [2010]. The first author updated this database to include additional organizations engaged in CBWM using online information for a total of 304 organizations representing 10 provinces and two territories. Five main criteria were used to select case study groups from the database:

1. The group was well-established (6+ years) [Leach, Pelkey and Sabatier, 2002];

2. The group was engaged in long-term water monitoring (2+ years);

3. The group's CBWM data had potentially been used in decision-making;

4. The group had at least one leader who had experience-based knowledge of the group's involvement in sharing monitoring information with government;

5. Both the group coordinator(s) and their government counterpart(s) were willing to participate in the study.

These criteria allowed the research team to narrow down the list of 304 organizations to 36 potential case study groups using available online information. The 36 potential case study groups were contacted by email and phone and 24 were successfully reached. After initial contact, 12 of these groups were determined to fit the majority of the case study criteria. Three of these 12 groups declined the invitation to participate and some did not fully meet the criteria upon further examination through phone calls. Four case study groups were selected; two from British Columbia because of clear examples of CBWM being used by government 
and influencing decision-making. A New Brunswick and a Prince Edward Island case were chosen because CBWM fed into a government process and there was a high potential to influence decision-making (see Table 1: Comparisons of case study watershed group characteristics). These four case studies provided an opportunity to present a wide geographical range of case studies as well as diversification from the research team's earlier focus on Ontario and Nova Scotia. West Coast and Ontario groups have been included in the same analysis in the past [Hunsberger, 2004], but not West Coast and Maritimes groups. Case studies were limited to four because of time and financial constraints.

Participants were recruited using 'gatekeeper' [Cloke et al., 2004] and 'snowball sampling' methods [Noy, 2008] and using contact information from the database. Semi-structured interviews were conducted between July 2013 and February 2014 with watershed group coordinators and government counterparts connected to the group for a total of 29 interviews (see Table 2: Participant recruitment). A semi-structured, in-depth style of interviewing enabled tailoring of the questions and prompts to the background and interests of the participants [DiCicco-Bloom and Crabtree, 2006; Johnson, 2002]. Data saturation was reached when themes became repetitive during the final interviews [Guest, Bunce and Johnson, 2006]. Watershed group coordinators included executive directors, directors, and project coordinators (present and past). Government counterparts included staff, managers, regional directors, and elected officials from municipal/local, regional, provincial, and federal levels (present and past). Site visits were made for all watershed groups and in-person interviews were conducted when possible; phone interviews (total of 12) were also conducted in cases where scheduling necessitated doing so. The study protocol was reviewed and approved by Dalhousie University's Social Science and Humanities Research Ethics Board and Saint Mary's University Research Ethics Board.

\section{Analysis}

Interviews were audio-recorded, transcribed verbatim, and analyzed following a simultaneous deductive-inductive coding method similar to a previous study [Fereday and Muir-Cochrane, 2006]. 'Coding' involves the assignment of codes (words or phrases) to sections of text to facilitate the organization of data within common themes for further analysis. The first author analyzed the interview transcripts using NVivo ${ }^{\mathrm{TM}}$ qualitative analysis software. The results reported in this paper were identified through open, inductive coding of the transcripts, which allowed for the inclusion of new factors and themes identified by the participants during the interviews [Fereday and Muir-Cochrane, 2006]. Codes produced during the first round of inductive coding were re-organized and condensed using established methods [Saldaña, 2008] and a second round was conducted to ensure consistency of existing codes and to identify new relevant codes (none were identified). The second author, a senior member of the research team, reviewed the inductive coding method prior to the second round of coding and deemed it to be appropriate. Preliminary findings for this paper were presented to participants and the research team through an online webinar and the findings resonated with those who attended, with no concerns brought to the team's attention. Participants were given the opportunity to review the preliminary analysis as well as quotations in context, and their feedback has been incorporated into the text. 
Table 1. Comparisons of case study watershed group characteristics.

\begin{tabular}{|c|c|c|c|c|}
\hline & \multicolumn{4}{|c|}{ Watershed Groups } \\
\hline Characteristics & $\begin{array}{l}\text { Quamichan } \\
\text { Watershed } \\
\text { Stewardship } \\
\text { Society }\end{array}$ & $\begin{array}{l}\text { Mid Vancouver } \\
\text { Island Habitat } \\
\text { Enhancement } \\
\text { Society }\end{array}$ & $\begin{array}{l}\text { Shediac Bay } \\
\text { Watershed } \\
\text { Association }\end{array}$ & $\begin{array}{l}\text { Bedeque Bay } \\
\text { Environmental } \\
\text { Management } \\
\text { Association }\end{array}$ \\
\hline Location & Duncan, BC & Parksville, BC & Shediac, NB & Summerside, PEI \\
\hline $\begin{array}{l}\text { Organization } \\
\text { established } \\
\text { (year) }\end{array}$ & 2006 & 1998 & 1999 & 1992 \\
\hline $\begin{array}{lr}\text { Reasons } & \text { for } \\
\text { initiation } & \text { of } \\
\text { the group } & \end{array}$ & $\begin{array}{l}\text { Concerned } \\
\text { lake-side residents, } \\
\text { assisted by } \\
\text { Cowichan Land } \\
\text { Trust }\end{array}$ & $\begin{array}{l}\text { Concerned salmon } \\
\text { fishers, evolved to } \\
\text { ecosystem-based } \\
\text { focus }\end{array}$ & $\begin{array}{l}\text { Concerned } \\
\text { residents, NB } \\
\text { Environmental } \\
\text { Trust Fund }\end{array}$ & $\begin{array}{l}\text { Environment } \\
\text { Canada's Atlantic } \\
\text { Coastal Action } \\
\text { Program }\end{array}$ \\
\hline $\begin{array}{l}\text { Watershed } \\
\text { health con- } \\
\text { cerns }\end{array}$ & $\begin{array}{l}\text { Eutrophication, } \\
\text { algae blooms, and } \\
\text { fishkills in } \\
\text { Quamichan Lake }\end{array}$ & $\begin{array}{l}\text { Drinking water } \\
\text { and salmon habitat } \\
\text { in the Englishman } \\
\text { River and } \\
\text { tributaries, estuary } \\
\text { habitat }\end{array}$ & $\begin{array}{l}\text { Residential, } \\
\text { forestry impacts in } \\
\text { Shediac Bay and } \\
\text { watershed } \\
\text { (Shediac and } \\
\text { Scoudouc Rivers) }\end{array}$ & $\begin{array}{l}\text { Nitrate, } \\
\text { sedimentation, and } \\
\text { fishkills in } \\
\text { Bedeque Bay } \\
\text { watershed (Dunk, } \\
\text { Wilmot, and } \\
\text { Bradshaw Rivers) }\end{array}$ \\
\hline $\begin{array}{l}\text { Long-term } \\
\text { monitoring } \\
\text { type* pro- } \\
\text { gram name } \\
\text { (when applic- } \\
\text { able), and lead } \\
\text { organization } \\
\text { name (when } \\
\text { different from } \\
\text { watershed } \\
\text { group). }\end{array}$ & $\begin{array}{l}\text { 1) Lake water } \\
\text { quality monitoring } \\
\text { 2) Multi-year } \\
\text { phosphorus } \\
\text { loading study (BC } \\
\text { Ministry of } \\
\text { Environment) }\end{array}$ & $\begin{array}{l}\text { 1) Stormwater } \\
\text { monitoring } \\
\text { (Automotive } \\
\text { Business } \\
\text { Stewardship } \\
\text { Project) } \\
\text { 2) Drinking water } \\
\text { quality and } \\
\text { watershed } \\
\text { monitoring } \\
\text { (Community } \\
\text { Watershed } \\
\text { Monitoring } \\
\text { Network - } \\
\text { Regional District } \\
\text { of Nanaimo, BC } \\
\text { Ministry of } \\
\text { Environment, } \\
\text { Island } \\
\text { Timberlands LP, } \\
\text { and watershed } \\
\text { groups) } \\
\text { 3) Freshwater } \\
\text { quality monitoring } \\
\text { (Water Quality } \\
\text { Objectives } \\
\text { Attainment } \\
\text { Monitoring - BC } \\
\text { Ministry of } \\
\text { Environment) }\end{array}$ & $\begin{array}{l}\text { 1) Freshwater } \\
\text { quality monitoring } \\
\text { 2) Estuarine water } \\
\text { quality and species } \\
\text { monitoring } \\
\text { (Community } \\
\text { Aquatic } \\
\text { Monitoring } \\
\text { Program - } \\
\text { Department of } \\
\text { Fisheries and } \\
\text { Oceans) } \\
\text { 3) Benthic } \\
\text { invertebrate and } \\
\text { freshwater quality } \\
\text { monitoring } \\
\text { (Canadian Aquatic } \\
\text { Biomonitoring } \\
\text { Network - } \\
\text { Environment } \\
\text { Canada) (past) }\end{array}$ & $\begin{array}{l}\text { 1) Freshwater } \\
\text { quality monitoring } \\
\text { (Wet-Pro }^{\text {TM}} \text { Toolkit } \\
\text { and Training } \\
\text { Program - } \\
\text { Community Based } \\
\text { Environmental } \\
\text { Monitoring } \\
\text { Network) } \\
\text { 2) Estuarine water } \\
\text { quality and species } \\
\text { monitoring } \\
\text { (Community } \\
\text { Aquatic } \\
\text { Monitoring } \\
\text { Program - } \\
\text { Department of } \\
\text { Fisheries and } \\
\text { Oceans) } \\
\text { 3) Benthic } \\
\text { invertebrate and } \\
\text { freshwater quality } \\
\text { monitoring } \\
\text { (Canadian Aquatic } \\
\text { Biomonitoring } \\
\text { Network - } \\
\text { Environment } \\
\text { Canada) } \\
\text { 4) School-based } \\
\text { freshwater quality } \\
\text { and watershed } \\
\text { characteristics } \\
\text { monitoring (Adopt } \\
\text { A River - } \\
\text { Education } \\
\text { Monitoring and } \\
\text { Action Group } \\
\text { G3E) } \\
\end{array}$ \\
\hline
\end{tabular}

*Includes fresh and estuarine water quality monitoring (2+ years). 
Table 2. Participant recruitment.

\begin{tabular}{|l|c|c|c|c|}
\hline $\begin{array}{l}\text { Interviewee Role } \\
\text { and Number of } \\
\text { Participants }\end{array}$ & $\begin{array}{c}\text { Quamichan } \\
\text { Watershed } \\
\text { Stewardship } \\
\text { Society }\end{array}$ & $\begin{array}{c}\text { Mid Vancouver } \\
\text { Island Habitat } \\
\text { Enhancement } \\
\text { Society }\end{array}$ & $\begin{array}{c}\text { Shediac Bay } \\
\text { Watershed } \\
\text { Association }\end{array}$ & $\begin{array}{c}\text { Bedeque Bay } \\
\text { Environmental } \\
\text { Management } \\
\text { Association }\end{array}$ \\
\hline $\begin{array}{l}\text { Watershed group } \\
\text { coordinators }\end{array}$ & 4 & 2 & 4 & 3 \\
\hline $\begin{array}{l}\text { Government } \\
\text { employees (staff } \\
\text { and managers) }\end{array}$ & 2 & 4 & 2 & 5 \\
\hline $\begin{array}{l}\text { Government } \\
\text { decision-makers } \\
\text { (elected official or } \\
\text { regional directors) }\end{array}$ & 1 & 1 & 7 & 0 \\
\hline $\begin{array}{l}\text { Total number of } \\
\text { interviewees }\end{array}$ & $\mathbf{7}$ & $\mathbf{7}$ & $\mathbf{7}$ & $\mathbf{8}$ \\
\hline
\end{tabular}

Over 50 percent of participants indicated that they wanted to be anonymous and, to maintain consistency; all participant quotations and paraphrases are indicated by a codename (e.g. "1-WC2" = Watershed Group Case Study 2 - Watershed Group Coordinator 2; "3-GR11" = Watershed Group Case Study 3 - Government Representative 11) (See Table 3: Codenames for watershed group case studies). Government representatives (including staff, managers, and decision-makers) were assigned a number from 1 to 16 , and watershed group coordinators were assigned a number from 1 to 13 .

Table 3. Codenames for watershed group case studies.

\begin{tabular}{|l|c|}
\hline Watershed Group Case Study & Number \\
\hline Quamichan Watershed Stewardship Society & 1 \\
\hline Mid Vancouver Island Habitat Enhancement Society & 2 \\
\hline Shediac Bay Watershed Association & 3 \\
\hline Bedeque Bay Environmental Management Association & 4 \\
\hline
\end{tabular}

Results

The findings presented in this paper were not the original focus of this study, nor were they intended as an analytic issue. However, during interviews with participants, it became evident that CBWM programs could be tailored to broader roles in environmental management and this had implications for organizations across Canada engaged in CBWM and warranted further analysis. Participants talked about two main roles for CBWM: 1) rigorous, scientific data collection that is useful for government, and 2) community awareness and engagement in stewardship. From discussions around monitoring design strengths and weaknesses for these two overlapping roles, three main categories were identified for monitoring program designs: 1) intensive monitoring that includes rigorous standards, is conducive to staff involvement, and is most useful for government, 2) integrated monitoring that can both engage community volunteers and include rigorous standards, and 3) basic monitoring that is ideal for broader community involvement and education. This categorization of CBWM designs, goals, and roles was derived from data associated with three key themes: 1) participant iterations of the differing roles, 2) the theme of matching monitoring design to the goals of the program, and 3) a summary of linkages between case study CBWM program 
designs and goals. The three categories for CBWM design reflected a potential gradient or spectrum of monitoring intensity. However, due to the study focus on the use of monitoring data in decision-making and subsequent over-representation of intensive and integrated study designs, our discussion is limited to these three categories and the application of a monitoring design spectrum requires future validation.

\section{Two overlapping roles for CBWM}

Several watershed group coordinators and government counterparts spoke of two overlapping roles for CBWM. These roles included: 1) scientific data that can be useful for government (and watershed groups), and 2) community awareness and engagement in stewardship. One federal government employee explained how different program designs feed into these roles:

'[The monitoring is] not done as a rigorous sampling but it's done... it's bringing the education of the public up to understand the importance of it. So you can do the monitoring at two levels. One is that rigorous data set that meets all the bells and whistles but there's also the educational monitoring...' (4-GR3).

A group coordinator supported the idea of both the technical, scientific role and educational role for monitoring when talking about a report that featured their CBWM results:

\footnotetext{
"We kind of wanted to do the [Status of the Bay] project with [Department of Fisheries and Oceans], which is more of a technical report for their purpose. Of course it's going to be useful for us too, it's supposed to be a living document. But then we wanted to make a more simple format too that would be helpful for us to get exposure and share information with the public so that they know what we're doing. And then get involved a little more... there were kind of two lines to this project" (3-WC1).
}

A federal government decision-maker said that as you get further away from a focus on rigorous scientific monitoring and closer to educational, stewardship role for monitoring, the monitoring becomes less directly useful for management decision-making but it becomes important in broader, strategic objective setting by the public (3-GR9), indicating the roles may be more similar to a spectrum.

The two extremes of monitoring program roles identified by participants resulted in the below conceptualizations for three main categories of CBWM designs (Table 4: CBWM program designs, goals, roles, strengths and weaknesses). The role of "rigorous sampling" mentioned by the first participant is interpreted to require an intensive monitoring design, and an "educational monitoring" role is interpreted to require a basic monitoring design. The third "integrated" design represents the combination of these two main roles. Monitoring programs in this study were also used for establishing baseline information, validating restoration activities, and flagging 'hotspot' water quality issues (see Table 5), and so the broader role of understanding watershed health is included in the conceptualization of roles as well. 
Table 4. Evaluation of CBWM program designs, goals, roles, strengths and weaknesses.

\begin{tabular}{|c|c|c|c|}
\hline & \multicolumn{3}{|c|}{ Monitoring Designs } \\
\hline & Intensive & Integrated & Basic \\
\hline $\begin{array}{l}\text { Monitoring } \\
\text { goals and } \\
\text { roles }\end{array}$ & $\begin{array}{l}\text { Inform governmental } \\
\text { decision-making; } \\
\text { increase focused } \\
\text { understanding of } \\
\text { watershed health and } \\
\text { establish baseline }\end{array}$ & $\begin{array}{l}\text { Inform governmental } \\
\text { decision-making and } \\
\text { engage communities; } \\
\text { increase understanding } \\
\text { of watershed health and } \\
\text { establish baseline }\end{array}$ & $\begin{array}{l}\text { Engage and educate } \\
\text { communities; } \\
\text { increase general } \\
\text { understanding of } \\
\text { watershed health and } \\
\text { establish baseline }\end{array}$ \\
\hline $\begin{array}{l}\text { Type of monit- } \\
\text { oring program }\end{array}$ & Government-led & $\begin{array}{l}\text { Multiparty and/or } \\
\text { independent/advocacy }\end{array}$ & Educational \\
\hline Characteristics & $\begin{array}{l}\text { High quality standards } \\
\text { and training; time } \\
\text { consuming; conducive } \\
\text { to staff involvement }\end{array}$ & $\begin{array}{l}\text { Adequate rigor and } \\
\text { training with some } \\
\text { design flexibility; can } \\
\text { range from } \\
\text { collaborative to } \\
\text { independent; staff or } \\
\text { volunteer involvement }\end{array}$ & $\begin{array}{l}\text { Very simple quality } \\
\text { standards and } \\
\text { training; easy; } \\
\text { conducive to } \\
\text { volunteer } \\
\text { involvement }\end{array}$ \\
\hline Strengths & $\begin{array}{l}\text { Credibility more easily } \\
\text { achieved; Can help to } \\
\text { inform long-term } \\
\text { governmental } \\
\text { decision-making; some } \\
\text { public participation }\end{array}$ & $\begin{array}{l}\text { Can simultaneously } \\
\text { engage communities } \\
\text { and inform } \\
\text { government, increasing } \\
\text { influence on } \\
\text { decision-making } \\
\text { (short-term and/or } \\
\text { long-term); high value } \\
\text { for resources }\end{array}$ & $\begin{array}{l}\text { Volunteers are more } \\
\text { easily engaged; } \\
\text { resource efficient; } \\
\text { promotes broad } \\
\text { community } \\
\text { awareness and can } \\
\text { produce short-term } \\
\text { results e.g. public } \\
\text { pressure }\end{array}$ \\
\hline Weaknesses & $\begin{array}{l}\text { Difficult to keep } \\
\text { volunteer motivation; } \\
\text { very resource intensive, } \\
\text { especially over } \\
\text { long-term }\end{array}$ & $\begin{array}{l}\text { Moderate resources } \\
\text { required; credibility } \\
\text { issues with advocacy } \\
\text { monitoring; } \\
\text { inter-organizational } \\
\text { collaboration can be } \\
\text { challenging }\end{array}$ & $\begin{array}{l}\text { Not able to be directly } \\
\text { used by government } \\
\text { due issues with rigor } \\
\text { and credibility. }\end{array}$ \\
\hline
\end{tabular}

\section{Matching CBWM programs designs to goals}

The CBWM programs included in each watershed group case study demonstrated a range of intensive, integrated, and basic monitoring designs, and their effectiveness in matching to their goals can be observed through their outcomes (Table 5). Several participants mentioned the importance of tailoring the CBWM design to the goals of the program, and challenges when these were mismatched. One federal government decision-maker suggested that the credibility issues with CBWM arise when there is a mismatch between the monitoring design and program goals (3-GR9). One provincial government employee suggested that refining a monitoring program to a group's financial resources helped to ensure the goals were achieved (4-GR1). Including volunteers or staff in the monitoring program was another design choice that affected the goals, as one watershed group coordinator explained:

'I guess it would be what's the objective of the program? Is it just to gather data or do you want more community education and involvement? If it's more education-based maybe you should be using more volunteers, because just having staff gather data doesn't really involve or educate people in the communities' (3-WC4). 
One participant from the same watershed group identified a trade-off between having a rigorous monitoring program and including volunteers:

'And that's the part we're struggling with. Trying to involve the public into what we're doing. But when you [involve volunteers in monitoring] you kind of lose a little bit of the robustness of results' (3-WC1).

The engagement of volunteers in monitoring had potential to strengthen educational goals beyond dissemination of findings to the public, but their engagement was seen to be in conflict with collecting rigorous data. An intensive/integrated monitoring program engaged volunteers in rigorous sampling of estuarine species and water quality, but the government employee indicated "that was one of the [constant] challenges [emphatic] with the groups was to keep their interest, and have volunteers involved" (3-GR7). This indicated a potential mismatch between intensive monitoring and volunteer engagement. A basic monitoring program that included easier sampling protocols was more conducive to volunteer involvement than a more rigorous, intensive program, as one group coordinator explained:

\begin{abstract}
'Adopt-A-River is more useful in the fact that... we do [Canadian Aquatic Biomonitoring Network (CABIN)], it's so regimented that you only have certain people that are trained in it. So your volunteer base is really small... Even though Adopt-A-River is a different level of sampling technique it's far more widespread, and we have far more volunteers, and it's far more intricate in the community' (4-WC5).
\end{abstract}

The Environment Canada program noted above (CABIN) engaged community volunteers and NGO staff in rigorous sampling and certification and created valuable baseline data for government, but the high cost of certification was prohibitive for the involvement of many community groups (4-WC5). An integrated monitoring program was able to both produce monitoring data that were useful for government and to enhance community awareness, but they had to adapt the training to volunteer needs and ensured that the monitoring equipment and parameters they selected were "simple, straightforward" (1-GR11). One government employee highlighted an inherent challenge of engaging volunteers in long-term monitoring, even when the design was integrated:

"[W]hen you work with locals, they don't understand that government is slow [emphatic]. No matter what government you deal with, whether its local, provincial, federal, things take time. Like you can't sample in one year and expect changes to happen" (2-GR13).

This participant highlighted volunteer needs for short-term rewards, and helping to explain why engaging volunteers in long-term monitoring could be challenging. For another integrated monitoring program their group coordinator highlighted the importance of their monitoring program for supporting their broader goal: 'The monitoring is to support the validity of the action we are taking which we believe [emphatic] is cleaning up the lake' (1-WC6). Their monitoring program included volunteers, adequate standards of rigor, and they shared the results with 
landowners to build public support for influencing a local government decision. Aligning monitoring program designs to goals thus required careful consideration of the needs for rigor, volunteer engagement, and availability of resources as well as the role of CBWM in environmental management.

Table 5: Case study CBWM program examples with alignment between monitoring goals, design, and outcomes showing match/mismatch (as illustrative, not comprehensive examples).

\begin{tabular}{|c|c|c|c|}
\hline $\begin{array}{l}\text { Case Study } \\
\text { CBWM Program } \\
\text { Examples } \\
\end{array}$ & $\begin{array}{l}\text { Monitoring Goals } \\
\text { (for both watershed } \\
\text { group and program) }\end{array}$ & $\begin{array}{l}\text { Monitoring Design } \\
\text { (Intensive, Integrated } \\
\text { or Basic) }\end{array}$ & $\begin{array}{l}\text { Outcomes Indicating a } \\
\text { Match/Mismatch with } \\
\text { Goals and Design }\end{array}$ \\
\hline $\begin{array}{l}\text { Case study: } \\
\text { Quamichan } \\
\text { Watershed } \\
\text { Stewardship } \\
\text { Society } \\
\text { CBWM Program: } \\
\text { Long-term lake } \\
\text { water monitoring } \\
\text { program }\end{array}$ & $\begin{array}{l}\text { Demonstrate the } \\
\text { nutrient issues in the } \\
\text { lake; involve and } \\
\text { educate the community; } \\
\text { inform the management } \\
\text { plan for improving lake } \\
\text { water quality; validate } \\
\text { remediation activities. }\end{array}$ & $\begin{array}{l}\text { Integrated } \\
\text { The Ministry of } \\
\text { Environment provided } \\
\text { training, design } \\
\text { assistance, and } \\
\text { equipment (including } \\
\text { calibration); 1-2 regular } \\
\text { volunteers; quarterly } \\
\text { monitoring (Secchi } \\
\text { depth, oxygen, } \\
\text { temperature, colour } \\
\text { observation). }\end{array}$ & $\begin{array}{l}\text { Match } \\
\text { Engaged community } \\
\text { around the lake through } \\
\text { information sharing } \\
\text { and presented a petition } \\
\text { to local government, } \\
\text { central sewer system } \\
\text { was extended; lake } \\
\text { remediation through air } \\
\text { bubbling system. }\end{array}$ \\
\hline $\begin{array}{l}\text { Case study: Mid } \\
\text { Vancouver Island } \\
\text { Habitat } \\
\text { Enhancement } \\
\text { Society } \\
\text { CBWM Program: } \\
\text { Regional District } \\
\text { of Nanaimo } \\
\text { watershed } \\
\text { monitoring pilot } \\
\text { project } \\
\text { (Ministry of } \\
\text { Environment/ } \\
\text { Regional District } \\
\text { of Nanaimo) }\end{array}$ & $\begin{array}{l}\text { Assess trends in } \\
\text { watershed health and } \\
\text { feed into provincial } \\
\text { water quality } \\
\text { monitoring; raise } \\
\text { community awareness } \\
\text { of watershed health } \\
\text { issues; eventually assist } \\
\text { Regional District in } \\
\text { land-use planning }\end{array}$ & $\begin{array}{l}\text { Integrated } \\
\text { Province and regional } \\
\text { district involved in } \\
\text { design phase, training, } \\
\text { and provide equipment; } \\
\text { volunteers engaged } \\
\text { weekly during summer } \\
\text { low flow and fall rain } \\
\text { periods measuring } \\
\text { turbidity, conductivity, } \\
\text { oxygen, and } \\
\text { temperature; Island } \\
\text { Timberlands LP } \\
\text { contributes to lab fees. }\end{array}$ & $\begin{array}{l}\text { Match } \\
\text { Guides provincial } \\
\text { monitoring and for } \\
\text { evaluating long-term } \\
\text { trends; Helped to } \\
\text { identify water quality } \\
\text { issue related to failing } \\
\text { septic tanks and } \\
\text { resulted in letters being } \\
\text { written to landowners } \\
\text { by Regional District; } \\
\text { greater community } \\
\text { understanding resulted } \\
\text { in less angry phone } \\
\text { calls. }\end{array}$ \\
\hline $\begin{array}{l}\text { Case study: Mid } \\
\text { Vancouver Island } \\
\text { Habitat } \\
\text { Enhancement } \\
\text { Society } \\
\text { CBWM Program: } \\
\text { Water quality } \\
\text { objectives } \\
\text { attainment } \\
\text { monitoring } \\
\text { (Environment } \\
\text { Canada/ Ministry } \\
\text { of Environment) }\end{array}$ & $\begin{array}{l}\text { Assess provincial water } \\
\text { quality objectives over } \\
\text { the long-term }\end{array}$ & $\begin{array}{l}\text { Intensive } \\
\text { Province provides } \\
\text { supervision and } \\
\text { training and federal } \\
\text { government provides } \\
\text { funding; volunteers } \\
\text { collect water and } \\
\text { benthic invertebrate } \\
\text { samples; } 2 \text { week } \\
\text { periods every } 5 \text { years. }\end{array}$ & $\begin{array}{l}\text { Match } \\
\text { Water quality objectives } \\
\text { continue to be assessed; } \\
\text { Supported water } \\
\text { quality issue identified } \\
\text { related to failing septic } \\
\text { tanks and resulted in } \\
\text { letters being written by } \\
\text { the Regional District to } \\
\text { landowners to } \\
\text { encourage them to } \\
\text { hook-up to sewer } \\
\text { system. }\end{array}$ \\
\hline
\end{tabular}

Continued on the next page 
Table 5: Continued from the previous page.

\begin{tabular}{|c|c|c|c|}
\hline $\begin{array}{l}\text { Case Study } \\
\text { CBWM Program } \\
\text { Examples } \\
\end{array}$ & $\begin{array}{l}\text { Monitoring Goals } \\
\text { (for both watershed } \\
\text { group and program) }\end{array}$ & $\begin{array}{l}\text { Monitoring Design } \\
\text { (Intensive, Integrated } \\
\text { or Basic) }\end{array}$ & $\begin{array}{l}\text { Outcomes Indicating a } \\
\text { Match/Mismatch with } \\
\text { Goals and Design }\end{array}$ \\
\hline $\begin{array}{l}\text { Case study: Mid } \\
\text { Vancouver Island } \\
\text { Habitat } \\
\text { Enhancement } \\
\text { Society } \\
\text { CBWM Program: } \\
\text { Automotive } \\
\text { Stewardship } \\
\text { Sampling } \\
\text { Program }\end{array}$ & $\begin{array}{l}\text { Reduce the impact of } \\
\text { storm water pollution; } \\
\text { provide a baseline for } \\
\text { storm water near } \\
\text { automotive businesses; } \\
\text { increase awareness of } \\
\text { automotive business } \\
\text { owners; promote } \\
\text { multi-stakeholder } \\
\text { stewardship in the } \\
\text { watershed. }\end{array}$ & $\begin{array}{l}\text { Integrated } \\
\text { Province helped with } \\
\text { study design, provided } \\
\text { equipment/lab } \\
\text { analysis; volunteers } \\
\text { collected sediment and } \\
\text { water samples; } \\
\text { re-measured water } \\
\text { quality after visiting } \\
\text { with automotive } \\
\text { businesses to track } \\
\text { changes. }\end{array}$ & $\begin{array}{l}\text { Match } \\
\text { Volunteers explained } \\
\text { results to business } \\
\text { owners and best } \\
\text { management practices } \\
\text { for remediating } \\
\text { pollutants; newspaper } \\
\text { article of companies } \\
\text { that made changes to } \\
\text { pollutants released and } \\
\text { companies that didn't. }\end{array}$ \\
\hline $\begin{array}{l}\text { Case study: } \\
\text { Shediac Bay } \\
\text { Watershed } \\
\text { Association } \\
\text { CBWM Program: } \\
\text { Long-term water } \\
\text { quality } \\
\text { monitoring } \\
\text { (New Brunswick } \\
\text { Water } \\
\text { Classification } \\
\text { Program) }\end{array}$ & $\begin{array}{l}\text { Enhance community } \\
\text { understanding and } \\
\text { awareness of watershed } \\
\text { health; validate } \\
\text { watershed restoration } \\
\text { efforts and pinpoint } \\
\text { issue areas; long-term } \\
\text { collection and storage } \\
\text { of baseline information; } \\
\text { inform the Water } \\
\text { Classification } \\
\text { Regulation. }\end{array}$ & $\begin{array}{l}\text { Intensive to integrated } \\
\text { Province provides } \\
\text { funding, initial training, } \\
\text { and sampling design; } \\
\text { summer staff collect } \\
\text { samples for } 6 \text { months } \\
\text { annually; group owns a } \\
\text { YSI probe for } \\
\text { measuring physical and } \\
\text { chemical parameters; } \\
\text { send samples to lab for } \\
\text { nitrates, phosphates, } \\
\text { E.coli, and total } \\
\text { coliforms. }\end{array}$ & $\begin{array}{l}\text { Match } \\
\text { Results included in a } \\
\text { Status of the Bay report } \\
\text { in 2006; Ongoing } \\
\text { restoration activities } \\
\text { and annual reports. } \\
\text { Mismatch } \\
\text { The Province continues } \\
\text { to delay } \\
\text { implementation of the } \\
\text { Water Classification } \\
\text { Regulation; Two } \\
\text { coordinators indicated } \\
\text { that including } \\
\text { volunteers could } \\
\text { enhance educational } \\
\text { goals. }\end{array}$ \\
\hline $\begin{array}{l}\text { Case study: } \\
\text { Shediac Bay } \\
\text { Watershed } \\
\text { Association } \\
\text { CBWM Program: } \\
\text { Community } \\
\text { Aquatic } \\
\text { Monitoring } \\
\text { Program } \\
\text { (Department of } \\
\text { Fisheries and } \\
\text { Oceans-Southern } \\
\text { Gulf of St. } \\
\text { Lawrence } \\
\text { Coalition on } \\
\text { Sustainability) }\end{array}$ & $\begin{array}{l}\text { Raise community } \\
\text { awareness of estuarine } \\
\text { ecology, collect baseline } \\
\text { data on estuarine } \\
\text { species, and assess } \\
\text { species composition in } \\
\text { estuaries. }\end{array}$ & $\begin{array}{l}\text { Intensive to integrated } \\
\text { Department of Fisheries } \\
\text { and Oceans and } \\
\text { Southern Gulf of Saint } \\
\text { Lawrence Coalition on } \\
\text { Sustainability jointly } \\
\text { run the program for } \\
\text { three months in the } \\
\text { summer; volunteers } \\
\text { help to assess estuarine } \\
\text { species and collect } \\
\text { water samples at six } \\
\text { sites once a month. }\end{array}$ & $\begin{array}{l}\text { Match } \\
\text { Data increases } \\
\text { decision-maker } \\
\text { understanding of } \\
\text { estuarine species; the } \\
\text { data is contributed to a } \\
\text { research partnership; } \\
\text { involves volunteers at } \\
35 \text { sampling sites. } \\
\text { Mismatch } \\
\text { Government employee } \\
\text { said volunteer } \\
\text { engagement is a } \\
\text { constant challenge. }\end{array}$ \\
\hline
\end{tabular}


Table 5: Continued from the previous page.

\begin{tabular}{|c|c|c|c|}
\hline $\begin{array}{l}\text { Case Study } \\
\text { CBWM Program } \\
\text { Examples } \\
\end{array}$ & $\begin{array}{l}\text { Monitoring Goals } \\
\text { (for both watershed } \\
\text { group and program) }\end{array}$ & $\begin{array}{l}\text { Monitoring Design } \\
\text { (Intensive, Integrated } \\
\text { or Basic) }\end{array}$ & $\begin{array}{l}\text { Outcomes Indicating a } \\
\text { Match/Mismatch with } \\
\text { Goals and Design }\end{array}$ \\
\hline $\begin{array}{l}\text { Case study: } \\
\text { Bedeque Bay } \\
\text { Environmental } \\
\text { Management } \\
\text { Association } \\
\text { CBWM Program: } \\
\text { Canadian Aquatic } \\
\text { Biomonitoring } \\
\text { Network } \\
\text { (Environment } \\
\text { Canada) }\end{array}$ & $\begin{array}{l}\text { Assess long-term } \\
\text { watershed health status } \\
\text { trends through } \\
\text { interagency } \\
\text { collaboration; } \\
\text { supplement } \\
\text { government water } \\
\text { quality monitoring; } \\
\text { identify issues and } \\
\text { validate restoration } \\
\text { activities }\end{array}$ & $\begin{array}{l}\text { Intensive to integrated } \\
\text { Environment Canada } \\
\text { provides a } \\
\text { biomonitoring } \\
\text { certification program, } \\
\text { rigorous training, a } \\
\text { central database and } \\
\text { analysis tools; in the } \\
\text { fall, group staff collect } \\
\text { benthic } \\
\text { macroinvertebrates } \\
\text { (identified to } \\
\text { genus/species) and } \\
\text { water quality samples } \\
\text { that are sent to } \\
\text { Environment Canada. }\end{array}$ & $\begin{array}{l}\text { Match } \\
\text { Information in national } \\
\text { database is used for } \\
\text { Environment Canada's } \\
\text { annual reporting; } \\
\text { BBEMA's restoration } \\
\text { activities are ongoing. } \\
\text { Mismatch } \\
\text { Costs of } \\
\text { macroinvertebrate } \\
\text { (\$250/site) and water } \\
\text { sample analysis are } \\
\text { prohibitive to many } \\
\text { groups. }\end{array}$ \\
\hline $\begin{array}{l}\text { Case study: } \\
\text { Bedeque Bay } \\
\text { Environmental } \\
\text { Management } \\
\text { Association } \\
\text { CBWM Program: } \\
\text { Wet-Pro }{ }^{\mathrm{TM}} \\
\text { training and } \\
\text { toolkit (Saint } \\
\text { Mary's University) }\end{array}$ & $\begin{array}{l}\text { Long-term baseline } \\
\text { information on } \\
\text { watershed health; } \\
\text { validate restoration } \\
\text { activities; raise } \\
\text { awareness of surface } \\
\text { and groundwater health } \\
\text { issues through public } \\
\text { engagement and } \\
\text { education }\end{array}$ & $\begin{array}{l}\text { Integrated } \\
\text { University-based } \\
\text { certification program } \\
\text { (multi-stakeholder } \\
\text { design input); } \\
\text { peer-to-peer training } \\
\text { model; summer staff } \\
\text { use YSI probe to } \\
\text { measure nitrates, pH, } \\
\text { dissolved oxygen, and } \\
\text { others; water samples } \\
\text { sent to provincial lab. }\end{array}$ & $\begin{array}{l}\text { Match } \\
\text { Collection of long-term } \\
\text { baseline data and } \\
\text { storage in centralized } \\
\text { database; government } \\
\text { interest in long-term } \\
\text { data; restoration } \\
\text { activities ongoing; } \\
\text { training of other groups } \\
\text { in monitoring and } \\
\text { water quality sampling } \\
\text { service for well-owners. }\end{array}$ \\
\hline $\begin{array}{l}\text { Case study: } \\
\text { Bedeque Bay } \\
\text { Environmental } \\
\text { Management } \\
\text { Association } \\
\text { Program: } \\
\text { Adopt-A-River }\end{array}$ & $\begin{array}{l}\text { Children's science } \\
\text { education and } \\
\text { awareness of watershed } \\
\text { issues; basic baseline } \\
\text { information on } \\
\text { watershed health; } \\
\text { validate restoration } \\
\text { activities. }\end{array}$ & $\begin{array}{l}\text { Basic } \\
\text { Provincial education } \\
\text { department provides } \\
\text { financial assistance for } \\
\text { training teachers and } \\
\text { equipment; Over } 20 \\
\text { schools (kids ages } \\
\text { 10-15) involved in } \\
\text { collection of } \\
\text { information on } \\
\text { macroinvertebrates } \\
\text { (identified to order), PH } \\
\text { (colour indicator); } \\
\text { dissolved oxygen, } \\
\text { nitrates, turbidity, } \\
\text { coliform bacteria. }\end{array}$ & $\begin{array}{l}\text { Match } \\
\text { Community outreach } \\
\text { and education (2350 } \\
\text { students since 2008); } \\
\text { classes create a } \\
\text { restoration and } \\
\text { management plan and } \\
\text { restore streams (e.g. tree } \\
\text { planting); database of } \\
\text { baseline water quality. }\end{array}$ \\
\hline
\end{tabular}

Community volunteers and organizations engage in CBWM for a variety of reasons, and program goals can range from informing restoration activities in the watershed, to promoting awareness of aquatic health issues, and to influencing policy at the local level [Latimore and Steen, 2014; Kebo and Bunch, 2013]. This paper has presented a way of conceptualizing an alignment between CBWM program designs, goals and roles in environmental management through the use of case study program examples and participant narratives. The intent of this paper is to highlight the importance of designing monitoring programs according to their 
goals and to help organisations engaged in CBWM maximize the use of their limited resources. There have been issues in the past with groups expecting their CBWM information to be useful for governments and other institutions (e.g., universities) and becoming frustrated when it is not used [Conrad, 2006]. The focus of this paper is on CBWM program goals that involve influencing governmental and other institutional decision-making in order to address this ongoing challenge. However, we also acknowledge and promote the diverse uses of CBWM that include informing stream restoration activities, promoting local conservation management action, and advocating for individual environmental behavioural change. We argue that CBWM designs include three main categories: 1) intensive monitoring (for informing governmental decision-making), 2) integrated monitoring (for informing government and promoting community awareness), and 3) basic monitoring (for community education and engagement). All of these CBWM program designs can help to enhance public awareness, establish baseline watershed health information, and identify emerging hotspot issues. However, tailoring CBWM programs to their strengths (and available resources) will help to maximize their effectiveness. When CBWM programs are aligned with their goals, they have the potential to enhance environmental management by addressing the evaluation of long-term trends by government and increased public engagement in watershed stewardship.

The importance of matching the monitoring design strengths to the goals of the program was emphasized by participants in this study and has also been highlighted in previous studies [Conrad and Daoust, 2008; Hunsberger, 2004; Whitelaw et al., 2003; Savan, Morgan and Gore, 2003; Vos, Meelis and Ter Keurs, 2000; Firehock and West, 1995]. Conrad and Daoust's [2008] functional framework for CBM suggests that the identification of goals is a key first step of a monitoring program. Meanwhile, Nerbonne and Nelson [2008] found that the goals of volunteer macroinvertebrate monitoring were often poorly aligned with the monitoring design, with high quality data being collected for community awareness goals and low quality data being used for policy change goals. Burdensome time commitment is known to be a main challenge for engaging CBWM volunteers [Kebo and Bunch, 2013] and the need for short-term rewards for volunteers was an important consideration in this study, helping to explain why intensive long-term monitoring is not as conducive to volunteer engagement. Sheppard and Terveen [2011] discourage this idea of a tension between opposing goals of scientific rigor and education, and found that an educational monitoring program helped students to learn about the rigors of the scientific process while ensuring the data were useful for government, showing that these goals can be mutually reinforcing. However, they also indicated that the program was well funded and supported in the school system [Sheppard and Terveen, 2011]. The combined attributes of scientific rigor and community participation have been found in other cases when the monitoring design was aligned to goals and adequate resources were available [Savan, Morgan and Gore, 2003; Latimore and Steen, 2014], supporting our study findings. Many organizations engaged in CBWM face capacity-related challenges [Danielsen, Burgess and Balmford, 2005; Sharpe and Conrad, 2006], and so a primary function of conceptualizing CBWM designs is maximizing the use of available resources. 
Standardized frameworks have been recommended for providing guidance to community groups that struggle to achieve their monitoring goals, such as influencing decision-making [Conrad and Hilchey, 2011; Conrad and Daoust, 2008; Pollock and Whitelaw, 2005] and watershed groups have favored functional over theoretical frameworks for monitoring [Conrad and Daoust, 2008]. While Danielsen and colleagues [2009] provide a similar conceptualization for linking monitoring approaches to goals in the context of natural resource management in developing countries, this study is the first to provide a practical typology of monitoring designs and goals for CBWM in a Canadian context. In the developing countries context, Danielson and colleagues devised a spectrum of approaches and evaluated the strengths and weaknesses based on observations from other studies, suggesting that with increasing local participation in monitoring, rigor and expense decreased while the ability to build community capacity and influence local decisions increased [Danielsen et al., 2009]. The identification of three overlapping categories for CBWM supports the idea of a spectrum suggested by Danielsen and colleagues [2009], as local participation in monitoring is seen as conducive to community engagement and stewardship. This study adds to this work by characterizing CBWM design categories that are informed with empirical research, including case study examples of program alignment between designs and goals.

The monitoring program designs outlined in this study can be linked with the four CBM types described by Whitelaw and colleagues [2003] however, there are complexities that may make direct linkages more difficult in practice. The categories of intensive, integrated, and basic monitoring designs reflect decreasing government and academic professional involvement in CBM types: government-led monitoring, multiparty monitoring, advocacy monitoring, and interpretative/educational monitoring (see Table 4). This sequence works while it assumes that rigor increases with intensity of sampling design and government involvement, which is supported by Danielsen and colleagues [2009]; however, another study found that scientific rigor increases with group autonomy, thus decreasing with the involvement of professionals [Nerbonne and Nelson, 2008]. Nerbonne and Nelson's finding challenges the commonly held notion of a tension between volunteer involvement and rigor, which was reiterated by some participants in this study. Furthermore, Lawrence [2006] suggests that a top-down to bottom-up understanding of monitoring may disregard complexities inherent in the relationship between scientific data collection and community awareness and engagement. They emphasize that internal values (e.g. educational) and external values (e.g. rigorous data) of monitoring can be observed in the same program [Lawrence, 2006], much like the cases of integrated design in our study. Instead of suggesting that intensive monitoring cannot raise community awareness and basic monitoring cannot produce usable data; we propose that intensive, integrated, and basic monitoring have particular strengths that can be tailored to desired goals according to the availability of resources, including equipment, volunteers, funding, and partners.

Matching the strengths of monitoring program designs to goals was found to have implications for the credibility of CBWM as well as volunteer engagement in this study. Monitoring programs that were designed with an adequate standard of rigor were most likely to achieve goals of informing governmental decision-making. Meanwhile, a basic monitoring program was the most conducive to volunteer involvement and contributed to broader community awareness and education. The 
link between matching design to program goals and enhanced credibility has been suggested in previous research [Hunsberger, 2004] and volunteer burnout has been cited as a recurring challenge [Whitelaw et al., 2003; Conrad, 2006]. Kebo and Bunch [2013] indicated that the main reason for reduced volunteer engagement is the large time commitment from scientific monitoring. Issues with credibility have been considered in the context of long-term, intensive monitoring [Conrad, 2006; Conrad and Daoust, 2008; Milne et al., 2006]; however, there has been less attention to the implications of a mismatch between design and goals for volunteer engagement and educational roles of CBWM in the literature.

A focus on the integration of CBWM with governmental decision-making in the literature [e.g. Conrad and Hilchey, 2011; Whitelaw et al., 2003; Danielsen, Burgess and Balmford, 2005] and interest from government in CBWM [e.g. Wieler, 2007; NSE, 2010] has coincided with an era of government decentralization and cutbacks for monitoring activities [Au et al., 2000]. Subsequently, there has been less focus in the literature on the more educational role of CBWM involving basic designs that can have wider influences on community awareness and education [exceptions include Cuthill, 2000 and Bliss et al., 2001]. While studies have found that many watershed groups seek to influence governmental decision-making through sharing of CBWM information [Conrad and Daoust, 2008; Milne et al., 2006], others have found that community education is considered by groups to be a main goal as well [Nerbonne and Nelson, 2008; Kebo and Bunch, 2013]. Nerbonne and Nelson [2008] found that 73 percent of volunteer benthic invertebrate monitoring groups surveyed in the United States included public education as a main goal for their programs while only 19 percent included influencing government policies, indicating that many groups consider the educational role of monitoring to be more important than influencing government policies. Considering the motivations of volunteers for monitoring is important for engaging communities in environmental management over the long-term [Cuthill, 2000; Measham and Barnett, 2008] as well as choosing potential goals for monitoring. Firehock and West [1995] highlighted the importance of considering multiple types of CBWM:

\footnotetext{
"As projects become more sophisticated by improving [quality assurance/quality control] and monitoring methods and by involving new partners, there is a danger that some groups may lose sight of one of the best reasons to conduct a volunteer monitoring project in the first place- increased public awareness" [p. 201].
}

The literature on citizen science has tended to focus on the scientific aspects rather than the process-oriented benefits, including the engagement of community members in science, indicating the need for a multifaceted view of success [Freitag and Pfeffer, 2013]. While educational outcomes are not often as obvious, volunteer stream monitoring programs were shown to have significant impacts on social networks of community participants, indicating a range of spinoff effects on local communities from volunteer engagement [Overdevest, Huyck Orr and Stepenuck, 2004]. This study helps to facilitate a more holistic view of CBWM and its potential roles in environmental management by identifying the strengths of each category of CBWM program design, including the integrated and basic monitoring designs that support greater community awareness and engagement. 
When monitoring design choices are considered carefully according to their strengths and suitability for desired goals, CBWM has the potential to feed into diverse aspects of environmental management decision-making. Vos and colleagues [2000], as well as one of our study participants, emphasized the importance of identifying a decision-making system for tailoring the design of monitoring programs to specific goals. Intensive monitoring that includes rigorous standards can feed into the information gathering phase of decision-making, where scientific evidence is balanced with economic, social, and other considerations [Pollard et al., 2008]. However, prior to information gathering, stakeholder concerns are identified for the prioritization of key issues [Pollard et al., 2008], and thus basic monitoring programs that include broad community engagement have potential to feed into this earlier phase of decision-making. Overdevest and colleagues [2004] found that volunteers were increasingly politically active the longer they were engaged in stream monitoring, for example engaging in discussions with neighbors about water quality issues. Involving local community members not only has potential to influence local decision-making, but also resulted in attitude changes towards environmentally sustainable management practices in one study [Gardner, 2010]. We emphasize governmental decision-making in this paper but it is also important to consider the use of CBWM in non-governmental decision-making with respect to watershed management. Watershed groups can use CBWM to provide feedback on the success of restoration projects [Garda, 2015] and identify priority areas for new educational programs or restoration projects. An integrated monitoring design can engage community members as well as produce rigorous scientific information useful for government and non-government organizations, feeding into multiple aspects of environmental management decision-making and contributing to community-led environmental stewardship.

Jønch-Clausen and Fugl [2001] suggest that public participation and awareness are vital to influencing decision-making in water resource management because of decreased government capacity and the need to prioritize. In this study, and others, increased local level participation in environmental monitoring was found to help influence local government decision-making [Danielsen et al., 2010] indicating the value of community volunteer engagement in integrated and basic monitoring designs. However, there are few studies that are able to make a direct link between public participation and improved decision-making [Ravenscroft, Curry and Markwell, 2002]. Decision-making is theorized to be a highly analytical process but is often strongly influenced by individual and societal concerns [Pollard et al., 2008] in addition to competing political forces, power relations, costs, and other factors [Colfer, 2008]. Multifaceted approaches to mobilizing knowledge gathered from monitoring, including community-led stewardship action, educational initiatives, and integration in government - or institution - led environmental management, will be necessary to facilitate environmentally sustainable behavior and policy changes.

The rise of CBWM across Canada is indicative of growing public interest in understanding environmental issues and becoming involved in environmental management and stewardship. There is also a desire amongst these groups to influence government decision-making and promote community awareness with CBWM; however, the best way to proceed has often been unclear. This study has 
attempted to clarify the strengths and weaknesses of three main CBWM program designs, including intensive monitoring that is most useful for informing government, integrated monitoring that can both engage communities and produce information useful for government, and basic monitoring that is more conducive to promoting community education and stewardship. There has been much less emphasis on basic, educational monitoring designs in the literature; however, engaging volunteers in monitoring can increase community awareness and concern for influencing the early prioritization phases of decision-making. Integrated monitoring shows the most potential for informing a holistic approach to influencing environmental management decision-making as it can achieve both adequate standards of rigor for informing government and engagement of community volunteers in hands-on learning about watershed issues, science, and environmental stewardship. All three CBWM program designs can help to inform baseline understanding of watershed health, flag emerging water quality issues, and guide watershed stewardship activities such as installation of digger logs. There is currently little guidance in the existing literature for watershed groups that want to use CBWM data to inform decisions around their environmental programs and projects. Further research is warranted on the links between multiple types of CBWM designs and their goals to validate these findings, particularly the link between basic monitoring program designs, their goals of community education, and influencing the early prioritization phase of environmental management decision-making. An examination of the assumption held by participants in this study and other studies [e.g. Danielsen et al., 2009] that data rigor increases with government and staff involvement would help to shed light on the role of government perceptions of credibility with CBWM [for contrast, see Nerbonne and Nelson, 2008]. This research has implications for assisting watershed groups in focusing CBWM efforts to areas of environmental management that will be most influential in their specific contexts and contribute to protecting the short-term and long-term health of watersheds. 'Methodology for public monitoring of total coliforms, Escherichia coli and toxicity in waterways by Canadian high school students'. Journal of Environmental Management 58 (3), pp. 213-230. DOI: 10.1006/jema.2000.0323.

Bakker, K. and Cook, C. (2011). 'Water Governance in Canada: Innovation and Fragmentation'. International Journal of Water Resources Development 27 (2), pp. 275-289. DOI: 10.1080/07900627.2011.564969.

Bliss, J., Aplet, G., Hartzell, C., Harwood, P., Jahnige, P., Kittredge, D., Lewandowski, S. and Soscia, M. L. (2001). 'Community-Based Ecosystem Monitoring'. Journal of Sustainable Forestry 12 (3), pp. 143-167. DOI: 10.1300/J091v12n03_07.

Bonney, R., Shirk, J. L., Phillips, T. B., Wiggins, A., Ballard, H. L., Miller-Rushing, A. J. and Parrish, J. K. (2014). 'Next Steps for Citizen Science'. Science 343 (6178), pp. 1436-1437. DOI: 10.1126/science.1251554.

Castleden, H., Crooks, V. A., Hanlon, N. and Schuurman, N. (2010). 'Providers' perceptions of Aboriginal palliative care in British Columbia's rural interior: Providers' perceptions of Aboriginal palliative care'. Health $\mathcal{E}$ Social Care in the Community 18 (5), pp. 483-491. DOI: 10.1111/j.1365-2524.2010.00922 .x.

Cloke, P., Cook, I., Crang, P., Goodwin, M., Painter, J. and Philo, C. (2004). Practising human geography. London, U.K.: Sage Publications Ltd. 
Colfer, C. J. P. (2008). ‘Chapter 16: From understanding to action: building on anthropological approaches to influence policymaking'. In: Against the grain: the vayda tradition in human ecology and ecological anthropology. Ed. by B. B. Walters, B. J. McCay, P. West and S. Lees. Lanham, MD, U.S.A.: AltaMira Press, pp. 273-286.

Conrad, C. (2006). 'Towards meaningful community-based ecological monitoring in Nova-Scotia: Where are we versus where we would like to be'. Environments Journal 34 (1), pp. 25-36.

Conrad, C. T. and Daoust, T. (2008). 'Community-Based Monitoring Frameworks: Increasing the Effectiveness of Environmental Stewardship'. Environmental Management 41 (3), pp. 358-366. DOI: 10.1007/s00267-007-9042-x.

Conrad, C. C. and Hilchey, K. G. (2011). 'A review of citizen science and community-based environmental monitoring: issues and opportunities'. Environmental Monitoring and Assessment 176 (1), pp. 273-291. DOI: 10.1007/s10661-010-1582-5.

Cuthill, M. (2000). 'An Interpretive Approach to Developing Volunteer-based Coastal Monitoring Programmes'. Local Environment 5 (2), pp. 127-137. DOI: 10.1080/13549830050009300.

Danielsen, F., Jensen, P. M., Burgess, N. D., Altamirano, R., Alviola, P. A., Andrianandrasana, H., Brashares, J. S., Burton, A. C., Coronado, I., Corpuz, N., Enghoff, M., Fjeldsa, J., Funder, M., Holt, S., Hubertz, H., Jensen, A. E., Lewis, R., Massao, J., Mendoza, M. M., Ngaga, Y., Pipper, C. B., Poulsen, M. K., Rueda, R. M., Sam, M. K., Skielboe, T., Sorensen, M. and Young, R. (2014). 'A Multicountry Assessment of Tropical Resource Monitoring by Local Communities'. BioScience 64 (3), pp. 236-251. DOI: 10.1093/biosci/biu001.

Danielsen, F., Burgess, N. D. and Balmford, A. (2005). 'Monitoring Matters: Examining the Potential of Locally-based Approaches'. Biodiversity and Conservation 14 (11), pp. 2507-2542. DOI: 10.1007/s10531-005-8375-0.

Danielsen, F., Burgess, N. D., Balmford, A., Donald, P. F., Funder, M., Jones, J. P. G., Alviola, P., Balete, D. S., Blomley, T., Brashares, J., Child, B., Enghoff, M., Fjeldså, J., Holt, S., Hübertz, H., Jensen, A. E., Jensen, P. M., Massao, J., Mendoza, M. M., Ngaga, Y., Poulsen, M. K., Rueda, R., Sam, M., Skielboe, T., Stuart-Hill, G., Topp-Jørgensen, E. and Yonten, D. (2009). 'Local Participation in Natural Resource Monitoring: a Characterization of Approaches'. Conservation Biology 23 (1), pp. 31-42. DOI: 10.1111/j.1523-1739.2008.01063.x.

Danielsen, F., Burgess, N. D., Jensen, P. M. and Pirhofer-Walzl, K. (2010). 'Environmental monitoring: the scale and speed of implementation varies according to the degree of peoples involvement: Monitoring: participation boosts action'. Journal of Applied Ecology 47 (6), pp. 1166-1168. DOI: $10.1111 / j .1365-2664.2010 .01874 . x$.

Department of Fisheries and Oceans. Community Aquatic Monitoring Program (CAMP). URL: http://www.glf .dfo-mpo.gc.ca/Gulf/CAMP (visited on 14th May 2015).

DiCicco-Bloom, B. and Crabtree, B. F. (2006). 'The qualitative research interview'. Medical Education 40 (4), pp. 314-321. DOI: 10.1111/j.1365-2929.2006.02418.x.

Dickinson, J. L., Shirk, J., Bonter, D., Bonney, R., Crain, R. L., Martin, J., Phillips, T. and Purcell, K. (2012). 'The current state of citizen science as a tool for ecological research and public engagement'. Frontiers in Ecology and the Environment 10 (6), pp. 291-297. DOI: $10.1890 / 110236$. 
Dorcey, A. H. J. (1987). 'Research for water resources management: the rise and fall of great expectations'. In: Canadian Aquatic Resources. Ed. by M. C. Healey and R. R. Wallace. Canadian Bulletin of Fisheries and Aquatic Sciences 215. Ottawa, Canada: Fisheries and Oceans Canada, pp. 481-511.

Ely, E. (2008). 'Volunteer monitoring and the democratization of science'. The Volunteer Monitor 19, pp. 1-5.

Fereday, J. and Muir-Cochrane, E. (2006). 'Demonstrating rigor using thematic analysis: a hybrid approach of inductive and deductive coding and theme development'. International Journal of Qualitative Methods 5 (1), pp. 80-92. URL: ht tp://ejournals.library. ualberta.ca/index.php/IJQM/article/view/4411.

Firehock, K. and West, J. (1995). 'A Brief History of Volunteer Biological Water Monitoring Using Macroinvertebrates'. Journal of the North American Benthological Society 14 (1), pp. 197-202. DOI: 10.2307/1467734.

Fore, L. S., Paulsen, K. and O'Laughlin, K. (2001). 'Assessing the performance of volunteers in monitoring streams'. Freshwater Biology 46 (1), pp. 109-123. DOI: $10.1046 / j .1365-2427.2001 .00640 . x$.

Freitag, A. and Pfeffer, M. J. (2013). 'Process, Not Product: Investigating Recommendations for Improving Citizen Science "Success"'. PLoS ONE 8 (5). Ed. by C. Nardini, pp. 1-5. DOI: 10.1371/journal . pone. 0064079.

Garda, C. (2015). 'Assessing aquatic ecosystem health benefits arising from activities associated with community-based monitoring'. Unpublished Thesis. Halifax, Nova Scotia, Canada: Dalhousie University.

Gardner, T. (2010). Monitoring forest biodiversity improving conservation through ecologically responsible management. London, U.K.: Earthscan, pp. 291-311.

Guest, G., Bunce, A. and Johnson, L. (2006). 'How many interviews are enough? An experiment with data saturation and variability'. Field Methods 18 (1), pp. 59-82. DOI: $10.1177 / 1525822 \times 05279903$.

Herron, E., Stepenuck, K., Green, L. and Addy, K. (2003). Designing your monitoring strategy: Basic questions and resources to help guide you. Factsheet. URL: http://blog.uvm.edu/kstepenu/files/2013/03/Guide_Designing_Your_Stra tegy_IV.pdf.

Hunsberger, C. (2004). 'Exploring the links between citizen environmental monitoring and decision-making: three canadian case examples'. Unpublished Thesis. Waterloo, Canada: University of Waterloo.

Johnson, J. (2002). 'In-depth interviewing'. In: Handbook of qualitative research. Ed. by J. Gubrium and J. Holstein. Thousand Oaks, CA, U.S.A.: Sage, pp. 103-119.

Jønch-Clausen, T. and Fugl, J. (2001). 'Firming up the Conceptual Basis of Integrated Water Resources Management'. International Journal of Water Resources Development 17 (4), pp. 501-510. DOI: 10.1080/07900620120094055.

Kebo, S. and Bunch, M. J. (2013). 'Canadian ENGOs in governance of water resources: information needs and monitoring practices'. Environmental Monitoring and Assessment 185 (11), pp. 9451-9460. DOI: $10.1007 / \mathrm{s} 10661-013-3264-6$.

Latimore, J. A. and Steen, P. J. (2014). 'Integrating freshwater science and local management through volunteer monitoring partnerships: the Michigan Clean Water Corps'. Freshwater Science 33 (2), pp. 686-692. DOI: 10.1086/676118.

Lawrence, A. (2006). 'No Personal Motive? Volunteers, Biodiversity, and the False Dichotomies of Participation'. Ethics, Place \& Environment: A Journal of Philosophy $\mathcal{E}$ Geography 9 (3), pp. 279-298. DOI: 10.1080/13668790600893319. 
Leach, W. D., Pelkey, N. W. and Sabatier, P. A. (2002). 'Stakeholder partnerships as collaborative policymaking: Evaluation criteria applied to watershed management in California and Washington'. Journal of Policy Analysis and Management 21 (4), pp. 645-670. DOI: 10.1002/pam. 10079.

Lefler, T. E. (2010). Successful Community-based Monitoring in Canada: Three Case Studies. Major Research Paper. Guelph, ON, Canada: University of Guelph.

Legg, C. J. and Nagy, L. (2006). 'Why most conservation monitoring is, but need not be, a waste of time'. Journal of Environmental Management 78 (2), pp. 194-199. DOI: $10.1016 / j \cdot j$ jenvman.2005.04.016.

Measham, T. G. and Barnett, G. B. (2008). 'Environmental Volunteering: motivations, modes and outcomes'. Australian Geographer 39 (4), pp. 537-552. DOI: $10.1080 / 00049180802419237$.

Milne, R., Rosolen, S., Whitelaw, G. and Bennett, L. (2006). 'Multi-party monitoring in Ontario: Challenges and emerging solutions'. Environments Journal 34 (1), pp. 11-23.

Nerbonne, J. F. and Nelson, K. C. (2008). 'Volunteer Macroinvertebrate Monitoring: Tensions Among Group Goals, Data Quality, and Outcomes'. Environmental Management 42 (3), pp. 470-479. DOI: 10.1007/s00267-008-9103-9.

Nova Scotia Environment (NSE) (2010). Water for life: Nova Scotia water resource management strategy. URL: https://www .novascotia.ca/nse/water. strategy/d ocs/WaterStrategy_Water. Resources. Management. Strategy . pdf (visited on 15th May 2015).

Noy, C. (2008). 'Sampling Knowledge: The Hermeneutics of Snowball Sampling in Qualitative Research'. International Journal of Social Research Methodology 11 (4), pp. 327-344. DOI: 10.1080/13645570701401305.

Overdevest, C., Huyck Orr, C. and Stepenuck, K. (2004). 'Volunteer stream monitoring and local participation in natural resource issues'. Research in Human Ecology 11 (2), pp. 177-185.

Pearse, P. H., Bertrand, F. and MacLaren, J. W. (1986). 'Currents of Change: Final Report, Inquiry on Federal Water Policy, Canada'. Environment: Science and Policy for Sustainable Development 28 (10). reviewed by Caulfield, Henry P., pp. 25-27. DOI: 10.1080/00139157.1986.9928838.

Pilon, P. J., Yuzyk, T. R., Hale, R. A. and Day, T. J. (1996). 'Challenges facing surface water monitoring in canada'. Canadian Water Resources Journal 21 (2), pp. 157-164. DOI: 10.4296/cwrj2102157.

Pollard, S. J. T., Davies, G. J., Coley, F. and Lemon, M. (2008). 'Better environmental decision making - Recent progress and future trends'. Science of The Total Environment 400 (1), pp. 20-31. DOI: 10.1016/j . scitotenv . 2008.07.022.

Pollock, R. M. and Whitelaw, G. S. (2005). 'Community-Based Monitoring in Support of Local Sustainability'. Local Environment 10 (3), pp. 211-228. DOI: 10.1080/13549839.2005.9684248.

Ravenscroft, N., Curry, N. and Markwell, S. (2002). ‘Outdoor Recreation and Participative Democracy in England and Wales'. Journal of Environmental Planning and Management 45 (5), pp. 715-734. DOI: 10.1080/0964056022000013084.

Saldaña, J. (2008). The coding manual for qualitative researchers. London, U.K.: Sage Publications Ltd. URL: https://uk. sagepub.com/en-gb/eur/the-codingmanual-for-qualitative-researchers/book243616. 
Savan, B., Morgan, A. J. and Gore, C. (2003). 'Volunteer Environmental Monitoring and the Role of the Universities: The Case of Citizens' Environment Watch'. Environmental Management 31 (5), pp. 561-568. DOI: $10.1007 / \mathrm{s} 00267-002-2897-\mathrm{y}$.

Sharpe, A. and Conrad, C. (2006). 'Community Based Ecological Monitoring in Nova Scotia: Challenges and Opportunities'. Environmental Monitoring and Assessment 113 (1), pp. 395-409. DOI: 10.1007/s10661-005-9091-7.

Shelton, A. (2013). 'The accuracy of water quality monitoring data: a comparison between citizen scientists and professionals'. Masters Thesis. Halifax, NS, Canada: Saint Mary's University. URL: http://library2.smu.ca/xmlui/handle/01/25027.

Sheppard, S. A. and Terveen, L. (2011). 'Quality is a verb: the operationalization of data quality in a citizen science community'. In: Proceedings of the $7^{\text {th }}$ International Symposium on Wikis and Open Collaboration (WikiSym'11). New York, U.S.A.: Association for Computing Machinery. DOI: 10.1145/2038558. 2038565.

Sutherland, W. J., Pullin, A. S., Dolman, P. M. and Knight, T. M. (2004). 'The need for evidence-based conservation'. Trends in Ecology \& Evolution 19 (6), pp. 305-308. DOI: 10.1016/j.tree.2004.03.018.

Vaughan, H., Whitelaw, G., Craig, B. and Stewart, C. (2003). 'Linking ecological science to decision-making: Delivering environmental monitoring information as societal feedback'. Environmental Monitoring and Assessment 88 (1), pp. 399-408. DOI: 10.1023/A:1025593728986.

Vos, P., Meelis, E. and Ter Keurs, W. J. (2000). 'A framework for the design of ecological monitoring programs as a tool for environmental and nature management'. Environmental Monitoring and Assessment 61 (3), pp. 317-344. DOI: 10. 1023/A: 1006139412372.

Water Canada (2010). Monitoring Not Adequate: Vaughan. URL: http://watercanada.net/2010/monitoring-not-adequate-vaughan/ (visited on 4th May 2015).

West Coast Environmental Law (WCEL) (2004). "Please hold. Someone will be with you". A report on diminished monitoring and enforcement capacity in the Ministry of Water, Land, and Air Protection. Vancouver, BC, Canada: WCEL.

Whitelaw, G., Vaughan, H., Craig, B. and Atkinson, D. (2003). 'Establishing the Canadian Community Monitoring Network'. Environmental Monitoring and Assessment 88 (1), pp. 409-418. DOI: 10.1023/A:1025545813057.

Wieler, C. (2007). Delivery of ecological monitoring information to decision-makers (for the Ecological Monitoring and Assessment Network, Environment Canada). International Institute for Sustainable Development, pp. 1-87.

Amy Buckland-Nicks is a graduate of the Master of Environmental Studies program at the School for Resource and Environmental Studies, Dalhousie University in Halifax, Nova Scotia, Canada. She is currently the Climate Change Projects Coordinator at Bluenose Coastal Action Foundation, a watershed-based not-for-profit organization in Lunenburg, Nova Scotia, Canada.

E-mail: a.bucklan@gmail.com.

Dr. Heather Castleden is an Associate Professor and Canada Research Chair in Reconciling Relations for Health, Environments, and Communities at Queen's University in the Departments of Geography and Public Health Sciences in Kingston, Ontario, Canada. She is a health geographer and community-based 
participatory researcher. She is the Research Director at the Health, Environment, and Communities Research Lab (HEC Lab) (http://www.heclab.com/).

E-mail: heather.castleden@queensu.ca.

Dr. Catherine Conrad is a Professor in the Department of Geography at Saint Mary's University in Halifax, Nova Scotia and the Founder and Research Coordinator of the Community-Based Environmental Monitoring Network (www.envnetwork.smu.ca). Her research spans both science and social science, primarily with the engagement of communities and environmental organizations in the collection of citizen science and community mapping. Most recently she been working on community-based water monitoring and management in Nova Scotia via a project called CURA H2O (www.curah2o.com). E-mail: cconrad@smu.ca. community-based water monitoring program designs with goals for enhanced environmental management'. JCOM 15 (03), A01. 